\title{
ON THE PROSPECT OF WRITING CINEMA HISTORY FROM BELOW
}

Beginning with a consideration of recent discussions of the state of film history, this essay explores some aspects of the relationship between the historiography of cinema and broader currents in contemporary historiography, including the poststructuralist critique of history as a realist fiction. It engages with what one I970s theorist has recently called 'the weaknesses and insularity' of contemporary film studies by advocating the development of histories of cinema that place audiences, rather than films, at their centre, and integrate the quantitative methods of social history with the concrete and particular conditions of experience that are the predominant concern of microhistory. ${ }^{\mathrm{T}}$

\section{FILM HISTORIOGRAPHY: A MODEST CRITIQUE}

\section{Heroic theory and the 'New film history'}

In her contribution to a 2004 Cinema Journal forum on the state of film history, Sumiko Higashi questions the extent to which cinema studies has seen a turn toward history based on empirical research in the past two decades. Citing statistics on recent submissions to Cinema Journal and papers given at the Society of Cinema and Media Studies conference, she argues that the bypass onto the "historical turn" is far from crowded', a phenomenon she ascribes in part to the proposition that 'most academics who train students in film studies have not themselves been trained to do empirical research'. ${ }^{2}$ Seeking to differentiate between what she calls 'history proper' and work that she identifies as 'social and cultural media history', Higashi offers a critique of those 'film historians who began academic life as theoreticians' and remain deductive in their methodology. ' 'Proper' historians, by contrast, 'assume human agency; privilege empirical data (...) write with specificity and in great detail; eschew jargon; and make contingent, even contradictory generalisations. ${ }^{4}$

What is perhaps most striking about the essays in the Cinema Journal forum, including Higashi's, is the extent to which their debates over the nature of film history appear to be largely untouched by the central preoccupations of contemporary historiography, engendered by the fervent uncertainties of postmodern 
thought. Beyond the narrow confines of film studies, structuralist and poststructuralist critiques have deconstructed the conventionalised authorial voice of the history text, questioning its implicit rhetorical claim to authoritative knowledge of the past. ${ }^{5}$ Maintaining that the construction of history is a discursive act of narration unattached to the reality of the past, some theorists have gone further to argue that we can know nothing genuinely truthful about the past, both because the past is accessible to us only through its discursive traces and because 'historical narratives are verbal fictions, the contents of which are as much invented as found and the forms of which have more in common with their counterparts in literature than they have with those in the sciences'. ${ }^{6}$ Cinema historians' relative lack of engagement with poststructuralist theory's denial of the intellectual foundation of historical practice is both notable and, given the influence of poststructuralist thought on the development of film studies, somewhat surprising. ' Higashi's description of historical practice, for example, would rest comfortably alongside the account provided by a reflective but unreconstructed professional practitioner such as Arthur Marwick, who dismisses 'the postmodernist case' as a construct of 'a priori attitudes (...) rigid conventions (...) specialist language [and] lack of practical experience', and as a consequence 'irrelevant to the aims of working historians' ${ }^{8}$

In her contribution to the Cinema Journal forum, Jane Gaines suggests that film scholars' disengagement from questions of metahistory and the 'linguistic turn' in contemporary historiography is an indication of their relative sophistication. For Gaines, reading contemporary critiques of historical writing induces a sense of déjà vu, since the alleged defects of historical narrative - that readers are given 'the illusion of a privileged relation to the historical real' - echo those charges levelled in the I970s against 'the classic realist text'. ${ }^{9}$ While I share Gaines' sense of displaced familiarity, I suspect that a more substantial explanation for the relatively unreflective nature of film history's 'archive fever' lies elsewhere in the intellectual history of film studies as a field of enquiry, in the mutual antipathy between history and theory.

Writing about the I970s in their anthology of historical writing from Screen, editors Annette Kuhn and Jackie Stacey observe that 'the current of heroic theory then coursing with fervent energy through the pages of Screen' resulted in the journal's regarding an engagement with 'the new film history' as being 'tangential to its preoccupations with film language and with the ideological practices of cinema'. ${ }^{\text {Io }}$ The 'new film historians' then publishing revisionist histories of American cinema were themselves more concerned with winning some nineteenth-century historiographic battles than with engaging with poststructuralism. ${ }^{\text {II }}$ As Barbara Klinger described it, the most urgent task for film history in the late I970s was to 'displace secondary and anecdotal forms of history with primary documentation, archival research and other historiographical tools of evidence and verification'. ${ }^{\text {I2 }}$ In his 1976 Screen article on Warner Bros. and sound, for example, Douglas Gomery complained that earlier historians of the 
American film industry 'have not even followed the most basic practices of the field' in explaining their methodologies or citing their sources: 'no other brand of history is so casual in violating this basic attribute of scholarship'. ${ }^{13}$ The critique of existing survey histories offered by Gomery and Robert Allen in their I985 book Film History: Theory and Practice, that their omission of footnotes or bibliographies made it 'impossible to trace conclusions back to their evidentiary sources', might not have seemed out of place to Leopold von Ranke in I824. ${ }^{\mathrm{I}}$ Beginning from such a position, academic film history, which scarcely existed before the mid-I970s, spent most of its early years untroubled by external requirements that it address the uncertainties of contemporary historiography as they affected its more established relatives in other subject areas. As Allen and Gomery emphasised, its concerns were with the practical and organisational issues involved in undertaking the "tremendous amount of film historical scholarship' that remained to be done - with what Jeffrey Klenotic has called “ "rolling up their sleeves" in the face of the archive'. ${ }^{15}$ 'To do film history today', wrote Thomas Elsaesser in I986,

'one has to become an economic historian, a legal expert, a sociologist, an architectural historian, know about censorship and fiscal policy, read trade papers and fan magazines, even study Lloyds Lists of ships sunk in World War One to calculate how much of the film footage exported to Europe actually reached its destination'. ${ }^{\text {i6 }}$

The 'new film historians' were thus sufficiently engaged with problems of source and skills acquisition to add too many branches of poststructuralist theory to their list of responsibilities.

The tasks of the 'new film history' of the I970 and ig80 were threefold: to revise and correct the existing, under-researched histories that represented the available overviews of the period; to develop a film history that adhered more closely to the established protocols of academic historiography; and to provide an alternative mode of study to the dominant practices of textual interpretation, borrowed in the main from literary criticism and inflected with the concerns of semiotic, structuralist and psychoanalytic theories. As Klenotic commented, the methodological debates within film history remained 'centred over what should constitute "proper" or "valid" historical explanation' and were concerned to correct the historical record 'by re-examining the primary historical archive rather than relying on the secondary resources provided by prior histories' ${ }^{\text {I7 }}$ To take, perhaps, the most obvious example, Douglas Gomery's revisionist account of the innovation of sound technology corrected previous entertaining but inaccurate versions through its use of a much wider range of primary sources and its self-conscious adherence to what Philip Rosen has called the 'conventional kinds of protocols and venues of academic historiography', or what Higashi calls 'proper history'. ${ }^{\mathrm{I}}$ By comparison to previous accounts, no-one could seriously 
question the superior accuracy of Gomery's account, based on its broader evidentiary base and higher standards of critical evaluation and analysis. As Allen and Gomery pointed out in Film History, however, works of comparable scholarship and rigor were few and far between in the field, and it has simply taken time to build a sufficient body of consensual historical knowledge around which to stage a debate about historical method. Cinema history is still subject to the kinds of revelatory discovery - exemplified by Richard Abel's The Red Rooster Scare or Ruth Vasey's The World According to Hollywood - that seldom occur in the historiography of more established historical terrain, simply because the body of available primary source material pertaining to cinema has been far less thoroughly examined. ${ }^{\text {I9 }}$ There remains, to paraphrase Thomas Kuhn, a great deal of ordinary cinema history yet to be written. ${ }^{2 \circ}$

Except for occasional low-level skirmishes in pieces of academic journalism, the two camps of Theory and History largely ignored each other. Relatively few works of 'new film history' were - or indeed are- either published or reviewed in the most prominent theoretically-inflected journals, while the historians' suspicions of abstract theorizing has reproduced what Rosen calls 'the most traditional of modern disciplinary debates', first articulated in 'the rivalry between students of Hegel and Ranke at the foundations of the modern discipline of "History"'. ${ }^{2 \mathrm{I}}$ Rather than being conducted over the grounds of historical practice, however, the debate has largely taken place at a simplified level, in which 'History' and 'Theory' are placed in mutually uncomprehending opposition to each other. Discursive complexity continues to be taken as a sure sign of the presence of 'theory' while a plethora of footnotes, even if they are all to Variety, continues on the one hand to pass as a claim to historical veracity and on the other to lead to accusations of simple-minded 'empiricism'.

\section{Going nowhere: film history after deconstruction}

In his 200I book Change Mummified: Cinema, Historicity, Theory Philip Rosen provides the most fully elaborated account of the central propositions of the postmodern critique of history-writing as it pertains to the history of cinema. Rosen describes what he considers to be the basic uncertainty 'about the very possibility of making secure referential truth claims in historiography’ as resulting from two fundamental problems. ${ }^{22}$ The first relates to the fragmentary and indexical nature of historical evidence, the second to the position and referential authority of the historian. In common with many empirical historians, Rosen questions the extent to which the late twentieth-century critiques of modern historical practice have raised new epistemological and methodological issues, rather than merely rephrasing a set of concerns that have been repeatedly confronted by historians and philosophers of history. Few professional historians make claims for the absolute truth of their account, and whatever equivocation 
is involved in the maintenance of an ideal of more thoroughly reliable, less fragmentary knowledge of the past than is currently available, such pragmatic equivocation clearly also marks a recognition of the limits of the certainty with which any given account is produced. Ironically, however, there remains an apparently unbridgeable divide between the pragmatic equivocation expressed in E.H. Carr's answer to his own question What Is History?, that it is 'a continuous process of interaction between the historian and his facts, an unending dialogue between the present and the past', and the deconstructionist certainty that 'epistemology shows we can never really know the past; that the gap between the past and history (historiography) is an ontological one, that is, is in the very nature of things such that no amount of epistemological effort can bridge it'. ${ }^{23}$

Practicing historians have found themselves obliged to reject the poststructuralist critique - sometimes perhaps too vehemently - because in its assertion that the past is inherently unknowable it is so disabling to their practice. As Georg G. Iggers has observed, 'were one to accept the premises of this critique, meaningful historical writing would be impossible'. ${ }^{24}$ However salutary might be the critical reminders that every historical account is a discursive construct and every encounter with a source text an act of mediation, historians cannot practice their trade - the 'dirty and tedious archival work' of digging evidence out of sources - unless they regard the resulting account as bearing a plausible relation to an historical reality. ${ }^{25}$ As historian Carlo Ginzburg has argued, however, asserting this view does not, as the critique often asserts, involve naïvely assuming that the relationship between evidence and reality is transparent or unmediated. ${ }^{26}$ On the contrary, the recognition that

'all phases through which research unfolds are constructed and not given: the identification of the object and its importance; the elaboration of the categories through which it is analyzed; the criteria of proof; the stylistic and narrative forms by which the results are transmitted to the reader' requires that 'the obstacles interfering with re-search in the form of lacunae or misrepresentations in the sources must become part of the account'. ${ }^{27}$

In his commentary on Hayden White's Metahistory, Rosen observes that White and many subsequent rhetorical theorisations of historiography, have "continued the long-standing tendency among theorists of modern historiography to concentrate on the philosophical, ideological, metaphysical, and/or formal-aesthetic' aspects of the problem, and as a result have underplayed 'the implications of normative disciplinary procedures with respect to sources and evidence stemming from the heritage of the critical method'. ${ }^{28}$

The problems of writing film history under such constraints are exemplified by Vivian Sobchack's 'What is Film History?, or, the Riddle of the Sphinxes', in Christine Gledhill and Linda Williams' anthology, Reinventing Film Studies. The editors introduce Sobchack's essay as setting the stage for 'the new film history's 
theoretically informed historicizing of its objectives. No longer a simple matter of "excavating" original documents and material traces and causes of an objectively existing past, film history has taken on a self-reflective awareness of its own discursive processes of writing and mediation. ${ }^{29}$ Sobchack certainly talks the talk of the historical deconstructionists, describing a dichotomy between an 'old' and a 'new' history, in which

'Grand, coherent, and evolutionary narratives have given way to local and micro histories - and the gaps and ruptures in our knowledge of the past are foregrounded rather than smoothed over (...). history has lost its stability as the grounded site upon which knowledge of the past is accumulated, coherently ordered, and legitimated; rather, it has become an unstable site in which fragments of past representations do not necessarily 'add up' or cohere but, instead, are subject to "undisciplined" (and often "undisciplining”) contestation and use'. ${ }^{30}$

Exactly where this new self-reflective history has displayed its self-awareness is, however, more difficult to discern either in Sobchack's essay or in the references it lists. Instead, Sobchack elevates a somewhat quirky but otherwise unremarkable project in historical archaeology - the excavation of the remains of the sets for Cecil B. deMille's I923 movie THE TEN CoMmAn D M ENTs in the Guadalupe Dunes near Santa Barbara, California - into 'a symbol of the destabilised grounds of contemporary historical theory and practice', a 'revelatory allegory' of 'our increased estrangement from and desire to recuperate a history we know we never knew'. ${ }^{\text {I }}$ Asserting that 'a traditionalist empiricist [sic] film history whose temporal trajectory, causations, and meanings can be excavated, represented, and understood in terms of some linear, unidirectional, and progressive notion of "original" events and chronological "order" based upon the "coherence", "consistency", and "reliability" of an accumulation of "authentic" trace "evidence" left by the past' is no more than a 'crazy dream', Sobchack argues that the buried set represents 'a fabricated version of yet another lost Egyptian city whose "authenticity" and "origins" are irrecoverable, unknowable and hence historically "fabulous"'.32 What she fails to do, however, is to demonstrate what the destabilised and undisciplined 'historical nomadism' she advocates would tell us. Remaining true to her theoretical premises by declining to confront a concrete (or even a plaster-of-Paris) historical subject matter, Sobchack's essay envisions historical journeys that she might embark on, but goes nowhere. ${ }^{33}$ 


\section{Total histories of the film text}

The grand, coherent, evolutionary narratives of cinema history to which Sobchack alludes have been more imagined than actually written. ${ }^{34}$ In I973, Jean Mitry proposed an ideal of film history as

'simultaneously, a history of its industry, its technologies, its systems of expression (or, more precisely, its systems of signification), and aesthetic structures, all bound together by the forces of the economic, psychosocial and cultural order'. ${ }^{35}$

This version of film history as simultaneously medium-specific and totalising remains common to much contemporary film historiography, although its intellectual origins in the Annales School of French history are less often acknowledged. French film historian Michèle Lagny follows Mitry in describing her version of a preferred film history as 'a part of a larger ensemble, the sociocultural history (...) conceived as an articulation among three types of analysis, dealing with cultural objects, with the framework of their creation, making and circulation, and finally with their consumption'. She sees the desirable condition of film history as being that of 'an open field where different forces (economic, social, political, technical, cultural or aesthetic) come into being and confront each other'. She insists, however, that films are central to film history: 'the core is the film text, because only the film is the sign that cinema does exist (or doesn't exist any longer). Working from the cinema or on the cinema means starting from the film, and going back to it'. ${ }^{36}$

In her I997 Screen essay, 'Film History Terminable and Interminable', Barbara Klinger invokes Fernand Braudel's unattainable ambition 'if not to see everything, at least to locate everything, and on the requisite grand scale' before describing 'a cinematic histoire totale' that places 'a film within multifarious intertextual and historical frames', to produce a 'RASHOMON-like effect where the researcher uncovers different historical "truths" about a film as she/he analyses how it has been deployed within past social relations' and 'the film's variable, even contradictory, ideological meanings come into focus' ${ }^{37}$ The 'totalised perspective' that Klinger proposes 'provides a sense of what the historical prospects were for viewing at a given time by illuminating the meanings made available within that moment.$^{38}$ In keeping with Lagny's prescription, however, Klinger places the individual film text at the centre of the multifarious intersections she describes.

A consequence of the expectation that the film text must be the central object of film history surfaces in Richard Abel's argument, in his essay in the Cinema Journal forum, that Robert Allen's recent work on audiences in the American South 
'generally succeeds as social or cultural history more than as cinema history; that is, its chief interest lies in describing and analyzing the social conditions and cultural practices within which moving pictures could be as important for their relative absence as for their presence'. ${ }^{39}$

In common with the other historians I have cited, Abel remains reluctant to abandon the medium-specificity of film history in order to integrate it into what Charles Musser describes warily as 'a broader and more amorphous cultural and social history'. Musser declares that 'I have found it productive to imagine cinema as an element (typically a crucial element) of other histories', but the problem that film historians face is that relatively few writers of 'other histories' have shared Musser's sense of film history's productivity or importance..$^{40} \mathrm{De}$ spite the extensive historical analysis of early cinema, a recently-published 976 page history of late Victorian and Edwardian England, for example, devotes only one paragraph to cinema, providing a telling instance of the extent to which social and cultural historians have not yet found it necessary to address the historical work on early cinema. ${ }^{4 \mathrm{I}}$ In his 2004 introductory survey, What is Cultural History?, Peter Burke makes no mention of any work on cinema. ${ }^{42}$

In the second edition of Global Hollywood, published in 2004, Toby Miller and his colleagues come to bleak conclusions about the condition of screen studies, which they see as being irrelevant to both popular and policy-driven discussions of films and failing 'to engage political and social history and social theory on the human subject, the nation, cultural policy, the law and the economy'. ${ }^{43}$ 'What would it take', they ask, 'for screen studies to matter more?' Part of their answer is to avoid the "reproduction of "screen studies" in favour of work that studies the screen, regardless of its intellectual provenance'. ${ }^{44}$ One aspect of such a project may be to recognise the limited intellectual value in trying to maintain the coherence of a medium-specific academic discipline, and acknowledging, instead, that the study of the economics of distribution has little in common with the study of the aesthetics of lighting. More specifically, cinema's historians might question both the practicality and the ideal of an histoire totale, and consider the possibility of a history of cinema that is not centrally about films.

In a 1997 essay, James Hay argues that most film history has been written under the assumption of the centrality of the film text, producing a 'self-contained, self-perpetuating' aesthetic history of 'film as a distinct "language" or set of formal conventions (...) without a clear sense of cinema's relation to other social sites. ${ }^{45}$ While historical studies of cinema 'classicism' have examined the relationship between film form and mode of production, Hay suggests that they have seldom examined other determinations for the history of 'the cinematic', implying that cinema perpetuated itself as 'an aesthetic and an ideological effect regulated by a mode of production (...). In these studies, cinema is never understood overtly as a relation among sites and in terms of the relation of cinematic sites to other sites. ${ }^{46}$ 
Lee Grieveson, similarly, proposes that in an historical poetics which maintains 'the primacy of style' in the last instance, 'the possibility of the social affecting textuality is never simply denied but rather is bracketed off, giving priority to the examination of formal norms and industrial formations as "proximate" contexts'. ${ }^{47}$ Seeking a history that tracks 'the complex traffic between aesthetic and cultural spheres, making judicious interpretations of the connections that can be made and of the ways culture functions in texts, just as texts function in culture', Grieveson's project turns out to be similar to Klinger's, in aiming to 'situate cinema in relation to social, political, and cultural histories and at the confluence of questions about aesthetics, commerce, and power' ${ }^{48}$

\section{Proximate and approximate historical forces}

In response to Grieveson, David Bordwell has criticised the presupposition that while 'One can legitimately ask questions concerning aesthetic resources or strategies, (...) the answers will ultimately rest upon broader social, political, or cultural processes (law, economics, identity politics, etc.)':

'Does regulation, or response to "reform anxieties" (...) tell us why we have dialogue hooks, montage sequences, goal-oriented protagonists, and a switch from orthochromatic to panchromatic film stock? It seems unlikely (...) I suspect that many of the norms we trace [in The Classical Hollywood Cinema], at various levels of generality, are satisfactorily explained without invoking modernity, reform anxieties, moral discourse, or other factors simply because every explanation must stop somewhere, and it's impossible to spell out all the preconditions for any historical event'. ${ }^{49}$

Stylistic and technological histories of cinema can, obviously, be constructed from more tightly circumscribed evidentiary sources than cultural histories pursuing relationships of correspondence or congruence among contingent circumstances, but the sources an historian needs are determined by the question he or she is asking. Certainly, we can make more fine-grained distinctions among historical agencies than Bordwell allows. The files of the Production Code Administration are replete with specific examples of regulatory involvement with the production process, and the analysis of a broad sample of these records can establish both the specific stylistic effects of regulation and the specific influence of 'reform anxiety' on the content and appearance of movies at particular historical moments. 'Reform anxieties' in the early I930s, for example, challenged the industry's frequently-expressed view that if a movie told a properly moral narrative, in which good and evil were clearly distinguished and good seen to triumph, then the audience's moral principles would be reaffirmed. Arguing that young viewers failed to construct an 'organised interpretation' 
of a movie's narrative, Payne Fund researchers Herbert Blumer and Philip Hauser maintained that they were, instead, 'particularly responsive to incidents which are dramatic, exciting, and tempting'. As a result, they were likely to find 'details or elements of the picture' more significant than the moral contained in the movie's resolution..$^{\circ}$ This question became a central point at issue in the increasingly strident debate over movie censorship in the early I930s, and led to classical Hollywood's formulation of strategies of indeterminacy, elision, enigma and suggestion, which achieved the contradictory goal of presenting a predetermined narrative that simultaneously accommodated the viewer's imaginative agency. ${ }^{5 \mathrm{~T}}$

Pursuing a much less direct causal chain, what has become known as the 'modernity thesis' argues that the forms of early cinema 'engaged the experience of modernity', exemplifying a particularly modern form of aesthetics and responding to the specifics of modern and especially urban life..$^{52}$ Whether any of the advocates of modernity's influence on cinema insist that the relationship between modernity and cinematic style is a causal one is a point in dispute; its critics, however, maintain that the relationship is of consequence only if a causal linkage can be established, since otherwise the relationship is no more than an uninteresting generalisation, 'a commonplace that offers us nothing to investigate..$^{33}$

Modernity's advocates and their critics are engaging in quite different forms of enquiry, with separate aims and methodologies. One is a fine-grained examination of proximate forces that may provide causal explanations of particular stylistic decisions, the other a much broader consideration of the complex and elusive connections between a society and its cultural-aesthetic expressions. ${ }^{54}$ Addressing different questions by different methods at different levels of generality and detail, they are not necessarily in competition or in conflict with each other, yet each wishes the problems of an histoire totale upon the other, at the same time as they suggest that the other's view of historical determination is overly simplistic. Neither can meet the other's explanatory requirements. ${ }^{55}$ The history of textual relations and stylistic influence borrows its methods and rationale from the practices of art and literary history. It is predominantly a history of production and producers, concerned with issues of intention and agency underpinning the process of cultural production, usually at the level of the individual, and relatively little interested in anything - other than influence - that happens after the point of production. If the form of classical Hollywood cinema can, indeed, be sufficiently explained by the 'proximate forces' of 'industrial maturation and attempts at standardizing production practices' with little engagement with the history of cinema as a social or cultural institution, there is little reason for historians in other fields to be much concerned with the topic..$^{56}$

Broader cultural histories of cinema are, however, methodologically much more problematic, particularly in their capacity to demonstrate a sufficient degree of correspondence between an historical condition (for instance, the 
social conditions of the early Depression) and a cultural object (for instance, I AM A FUGITIVE FROM A CHAIN GANG) to argue for any causal relationship. As Bordwell observes, "why would we search for congruences unless they led us toward some explanatory hypotheses?' 57 Too often, explanation takes the form of textual interpretation, allowing the writer to juxtapose a movie and 'an array of social facts (...) about the concurrent social environment (...) as though media texts have some obvious direct relation to their social context', in a Zeitgeist account of film as cultural history. ${ }^{58}$ To argue, as Michèle Lagny does, that films should be seen 'socially and historically (...) as symptoms', advances us no further than the questionable methodology of ideological inference by allusion elaborated by Siegfried Kracauer in the late I940..$^{59}$ Borrowing such methodologies, social and political historians have incorporated back into their accounts of broader historical phenomena the genre-based, mythological and ahistorical assumptions about the relationship of movies to the culture of which they are a part. Even as they are incorporated into a larger version of social history, the movies remain under the obligation to entertain: accounts of I AM A FUGITIVE FROM A CHAIN GANG Or SCARFACE, for example, appear as diverting boxed features on 'social realism in the movies' to alleviate the statistical tedium of histories of the early Depression. Lagny's declaration of cinema's historical inconsequentiality ('[films] never are a consequence (of economic, social, cultural or political determining factors ...), nor the cause of anything (a political action, a social reaction, or the production of other films)' goes beyond Bordwell's circumscription and consigns cinema to the historical irrelevance it occupies in most accounts of twentieth-century history. ${ }^{60}$

\section{CINEMA HISTORY: A MODEST PROPOSAL}

\section{Reception and the condition of everyday life}

I am arguing for the desirability of distinguishing more emphatically between an aesthetic history of textual relations among individuals or individual objects, and the socio-cultural history of the economic institution of cinema. This distinction engages with the project advocated by Bordwell and Noël Carroll for 'piecemeal theorising' and 'middle-level research' that resists the hope that a Grand Interpretation will provide for 'a master reconciliation of all research programs'. ${ }^{6}$ The history of the American cinema is not exclusively the history of its products any more than the history of railroads is the history of locomotives. The development of locomotive design forms part of the history of railroads, but so, far more substantially, do government land policies and patterns of agricultural settlement. A history of cinema that will address the proposition 'that films, by improving the general quality and availability of entertainment at a low admission cost, contributed positively to the stock of social well-being, in the same way 
that low cost electric street lighting did by markedly improving the quality of illumination', will have significantly different concerns from film studies' preoccupation with the textuality of films, acts of interpretation of textual meaning and theoretical approaches to these acts of interpretation. ${ }^{62}$

A history of cinema that is not a history of textual relations among films must, however, be concerned with the history of reception, which must itself include histories of distribution and exhibition. One crucial feature of the history of the reception of American cinema is that for most audiences for most of the history of cinema, their primary relationship with 'the cinema' has not been with individual movies-as-artefacts or as texts, but with the social experience of cinema. ${ }^{{ }_{3}}$ An historical examination of the ways in which the cinema has provided a site and an occasion for particular forms of social behaviour, or of the ways in which individual movies have specified the nature of the site, the occasion, and the behaviour, is an enquiry into the production of meaning, but that meaning is social, not textual.

What would it take for cinema history to matter more? We can, perhaps, imagine some counter-factual historical circumstances. What if the Payne Fund Studies researchers had been right? What if the basic claims of effects, researchers since I9IO about the direct deleterious effects of movie consumption on youth, had any substance? What if the anti-American jeremiads of bourgeois cultural nationalists, that Hollywood movies 'literally poison the souls of our children, young people, young girls, who are to be turned into the docile slaves of the American multi-millionaires', accurately depicted the impact of American consumer products on other cultures? ${ }^{64}$ Were any of these propositions, with which so much commentary on the media remains preoccupied, demonstrable, we would find it much easier to raise grant money to study the history of cinema reception. We would also find it easier to persuade other historians of the significance of our research. So long as cinema history remains solipsistically committed to medium-specificity, starting and ending with the film text, then the history of entertainment will remain no more than an entertaining diversion occupying the illustrative margins of other histories. For cinema history to matter more, it must engage with the social history of which it is a part, not through the practices of textual interpretation, but by attempting to write cinema history from below; that is, to write histories that are concerned not with the kings and queens of Hollywood but with their audiences and with the roles that these performances of celebrity played in the ordinary imaginations of those audiences.

In part, I am advocating an historical return to the prevailing concerns of the earliest studies of cinema as an object of sociological and psychological enquiry, rather than the object of aesthetic, critical and interpretive enquiry that has ensued from the construction of film studies as an academic discipline in the humanities. These earlier studies, from Hugo Münsterberg to the Payne Fund research, concerned themselves with what Frankfurt School theorist Leo Lowenthal called 'the underlying social and psychological function' of cinema as 
a component in the modern urban environment; their methods were those of the 'human sciences', and their objects of enquiry were people, rather than artefacts. ${ }^{65}$ A return to such concerns in the history-writing that I am advocating invites an engagement by cinema historians with a different and far more productive, series of dialogues in social and cultural historiography since I970 than that provided by poststructuralism.

In the third quarter of the twentieth century, quantitative research methods permeated historical studies, underpinning claims that history was, like other social sciences, a scientific discipline. Demographic and economic histories, reliant on statistical data compiled from censuses or parish records, constructed a 'history without people', arguing that historians could examine those groups placed at the bottom of the social ladder only through the anonymity of quantitative data, in which, as E. P. Thompson wrote, 'working people are seen as a labour force, as migrants, or as the data for a statistical series'. ${ }^{66}$ In his quest to 'rescue the poor stockinger, the Luddite cropper (...) and even the deluded follower of Joanna Southcott, from the enormous condescension of posterity', Thompson sought to restore 'the agency of working people, the degree to which they contributed by conscious efforts to the making of history'. ${ }^{67}$ This aim was shared by several groups of historians concerned at the elimination of the particular in the grand narratives of social scientific history, who sought 'to reconstruct the lives of individual men and women from the popular classes of the past', with the specific purpose of reconstructing 'the relationship (about which we know so little) between individual lives and the contexts in which they unfold'. ${ }^{68}$

A history concerned with the conditions of everyday life as they are experienced by ordinary people requires, as George Iggers has argued, a new conceptual and methodological approach that sees history

'no longer as (...) a grand narrative in which the many individuals are submerged, but as a multifaceted flow with many individual centers (...) And if we are dealing with the individual lives of the many, we need an epistemology geared to the experiences of these many that permits knowledge of the concrete rather than the abstract'. ${ }^{69}$

Such histories of individual existence and experience are not, however, incompatible with those of broad social process. Ideally, the microhistories of Carlo Ginzburg and Giovanni Levy, extend, complement and qualify the broader generalisations provided by quantitative methods, and their dialogue provides models for the histories of cinema from below that I am advocating. ${ }^{70}$ To paraphrase Thompson, the aim of such histories would be to rescue the membership of cinema's audiences from the condescension of a posterity more concerned to contemplate 'its own desires, criteria, and representational structures for achieving historical coherence and meaning' than it is to construct a meaningful account of the past. ${ }^{7 \mathrm{I}}$ Like Barbara Klinger's histoire totale, such accounts would necessar- 
ily be contextual; the task is not so much a matter of trying to reconstruct the experiences of a particular cinema audience, largely unknown to each other, in a particular cinema at a particular screening on a particular day, as it is of seeking to understand the elements from which those experiences were constructed, on as specific a level of generalisation as the evidence may make available to us. For a history of cinema that is not centrally about films, however, the contexts to be invoked are quite different, as are the adjacent fields of knowledge that may be illuminated by a more fully-elaborated socio-cultural history of the economic institution of cinema. In the remainder of this paper, I briefly sketch three examples of the broader issues to which a history of cinema might be connected: demographics, Americanisation and consumption.

\section{Cinema and the histories of consumption}

As Robert Allen has argued, cinema history, and particularly the history of its audiences, is demographic history. ${ }^{72}$ A more exact sense of who made up cinema's audiences, and when, provides us with an alternative means of understanding cinema's cultural function as well as its product, but as yet relatively little work has been done in correlating broad demographic shifts against changing patterns of cinema attendance, or in mapping cinema provision against demographic data. In combination with other sources, such quantitative information has much to tell us about the changing composition of cinema's audiences over time, as well as about those sectors of the population largely excluded from attendance. I would, for example, argue that Richard Abel's recent investigations of 'how moving pictures circulated in medium- and small-sized cities' in the North-eastern United States in the I9IOs are methodologically entirely compatible with Allen's studies of cinema-attendance and non-attendance in the American South. Abel's aim of using data from those areas to interrogate cinema's role in either fostering 'a more or less homogeneous American mass public' or sustaining an 'ethnically and culturally heterogeneous society' forms part of the same broad about the place and function of cinema for its audiences that Allen is addressing. ${ }^{73}$

If, as Abel suggests, cinema played a significant role in the Americanisation of its urban population, its role in a more global process of Americanisation - that of 'sell[ing] America to the world with American motion pictures', as Will H. Hays proselytised in I923 - has long been asserted by both enthusiasts and detractors alike. Whether 'every film that goes from America abroad', has correctly portrayed 'the purposes, the ideals, the accomplishments, the opportunities, and the life of America', as Hays claimed it would, has been a subject of contention ever since. ${ }^{74}$ In April 200I, State Department spokesman Richard Boucher celebrated the accelerating expansion of the global market for American-sourced popular culture as a functional substitute for his department's dis- 
engagement from cultural diplomacy, by declaring to the Advertising Age that his department had now 'taken the view that to know us is to love us'. ${ }^{7}$ As early as I924, on the other hand, Secretary of State Charles Evans Hughes was complaining that the movies' 'false distortion of American life' had produced 'a pernicious distortion among other people with respect to the way in which our people live'. ${ }^{76}$

The shock following September II was not merely President Bush's amazement 'that there is such misunderstanding of what our country is about, that people would hate us'. ${ }^{77}$ It was also the shocked and apparently sudden recognition that the abandonment of cultural diplomacy to corporate commerce had not resulted in 'the triumph of American ideas'. ${ }^{78}$ Instead, suggested House International Relations Committee Chairman Henry Hyde, 'the country that invented Hollywood and Madison Avenue has allowed (...) a destructive and parodied image of itself to become the intellectual coin of the realm overseas' ${ }^{79}$ Viewed from abroad, where the concept of Americanisation has long carried fewer positive connotations and has more frequently been a term hovering somewhere between critique and abuse, the catastrophic failure of the ideological project encapsulated by Hays seems much less surprising. If the imaginary 'American' culture of the movies became, in Richard Kuisel's phrase, 'everyone's second culture', it did so far more successfully as an agent of commerce than as an instrument of ideology. ${ }^{80}$ As Victoria de Grazia has argued,

'it is not at all clear how as elusive a force as consumer culture, being the sum of myriads of marketing strategies, second-order decisions of government, and mundane choices about getting and spending, was converted into great power. Nor is it clear how the United States exercised this great power to promote democracies of consumption elsewhere, much less to advance global concord, ${ }^{81}$

Some of the histories of cinema I am proposing might reconsider Hollywood's role in 'the Americanisation of the world' by exploring the dissonance between the commercial and political effects of American cultural hegemony. ${ }^{82}$

In the decade after World War I, Hollywood became the most visible signifier of an unparalleled American economic expansionism, as the United States 'flooded the world with products, branch plants, and investment capital', while American radio and cable companies, wire services and airlines built the foundations of the American communications empire in what Owen D. Young, head of the Radio Corporation of America, described as the 'economic integration of the world'. ${ }^{83}$ To proponents such as Young and Hays, America's expansion was inherently benign, since it was based 'not on military force or government design but on the wonders of its private industry, the skill of its experts, the goodness of its philanthropists', and the ubiquity of its communications technologies. ${ }^{84}$ 'Film America', as the German trade press called Hollywood, was a 
powerful agent of this policy, as both a sales apparatus for American goods and as a demonstration of what de Grazia has characterised as 'the enduring capacity of the American "empire without frontiers" to discover, process, and redistribute techniques, styles, and tastes of global provenance'. ${ }^{85}$

In I929, economist Christine Frederick described this commercial version of Americanisation as 'Consumptionism (...) the greatest idea that America has to give to the world; the idea that workmen and masses be looked upon not simply as workers and producers, but as consumers. (...) Pay them more, sell them more, prosper more is the equation. ${ }^{86}$ In An All-Consuming Century, Gary Cross has argued that: 'Consumerism, the belief that goods give meaning to individuals and their roles in society', was 'the "ism" that won the political and ideological engagements of the twentieth century 'even though it had no formal philosophy, no parties, and no obvious leaders' ${ }^{87}$ Reflecting and often fulfilling real social needs, consumerism challenged class, religion, and ethnicity as principles of political solidarity, and 'succeeded where other ideologies failed because it concretely expressed the cardinal political ideals of the century - liberty and democracy - and with relatively little self-destructive behavior or personal humiliation'. ${ }^{88}$ Cross's uncommonly optimistic account of consumerism emphasises that the 'essential ambiguity of consumer goods was and is fundamental to their meaning and continued appeal'. The semantic malleability and complexity of consumer products have, in his analysis, been the source of their power to divert great social disharmonies into small, individualised disharmonies, to help 'individuals contend with social conflict and ambiguity, evade clear-cut choices, and even hold contradictory desires' ${ }^{89}$

Textual indeterminacy is a structural property of Hollywood movies, resulting from the economic conditions of their circulation: their distribution to a multiplicity of venues for a multiplicity of audiences, and the requirement that the single object serve multiple audience pleasures. Cross's arguments suggest that in this indeterminacy the movies both represented and embodied the semantic fluidity of consumerism itself. They were teaching their audiences the possibilities of pleasure in the democratisation of meaning, and of the power to interpret.

In her history of the spread of Americanised consumer culture in Europe from I900 to I970, de Grazia repeatedly demonstrates that different countries - and within each country different classes and groups - acquired the material capacity to participate in consumption at significantly different times. Undoubtedly, the movies, like advertising, reinforced a new economy of desire. But the public directly addressed by advertising - the public possessed of discretionary spending capacity - varied considerably from around $70 \%$ of the us population in the late I 20 s to $30 \%$ of the population of Britain and Northwest Europe, to less then Io\% of the population of Italy and Spain. Studies of the standards of living among American and European workers in Ford factories in 1929, for example, indicated such great differences in purchases of clothing, home conveniences and transport as to make comparison almost meaningless..$^{\circ}$ 
Writing about the differential spread of consumer durables in different parts of Europe in the I970s and I980s, de Grazia argues that the 'narrative of how household goods came to be possessed (...) was in large measure indifferent to variations in class, local cultures, and history'. At any given historical moment, however, what these goods meant, socially and culturally, varied from nation to nation and region to region depending on how far the particular nation or region had progressed through the reiterated narrative of 'technological change, rise in family incomes, and revolution in outlooks, all sanctioned and pushed by a new cross-Atlantic standard of living'.$^{\text {I }}$

Our present understanding of how cinema functioned as an agent of consumerism in both the us and abroad might stand some interrogation when considered in relation to the experience of consumption in different places at different times in the last century. If movies and movie attendance were classless, in the sense that it was a habit of all people of all classes, then in Europe they behaved differently from other, comparable consumer goods, which acted as sources of social fragmentation, producing 'new sources of differentiation and exclusion rather than making standards more homogeneous and accessible'..$^{2}$ But because movie attendance was geographically specific - attendance at this cinema in this neighbourhood with these people and these detailed local understandings of social distinction, attendance - and therefore exhibition - it could, clearly, not be separated from the patterns of social distinction in practical operation at the time. Indeed, as Christopher McKenna's work on the 'tripartheid' practices of segregation in Lumberton, North Carolina, shows, these patterns of social distinction had to be constructed into the architecture of the cinemas themselves..$^{93}$

To what extent did cinema, as a social agent in the promulgation of 'consumptionism', require pre-existing economic conditions, including a level of discretionary spending among its potential audience? Where these conditions did not exist, did cinema exhibition remain a marginal activity not simply because people were too poor to attend frequently, but also because the pleasures of cinema - the aspirational pleasures of viewing consumption and viewingas-consumption that were part of what economist Simon Pattern had called the surplus or pleasure economy - were insufficiently engaged with or integrated into their daily lives? ${ }^{94}$ Can we correlate patterns of cinema exhibition to the markedly variant patterns of retail sales in the us and Europe for much of the century? And if we can - or, for that matter, if we cannot - what will that tell us about the social function of cinema? Did cinema represent a sort of half-way house between access to 'Americanised' consumer culture and the practicalities of economic possibility, both for poorer communities in the us and for much of Europe in the first half of the 2 oth century and beyond? To what extent, where, and when, did the cinema provide a substitute for consumption - a placebo rather than an aspiration to consume and a guidebook or practical manual in the development of the practice of consumption? 
If the answers to these questions are not yet clear, what are somewhat clearer is that such explanations as we may be able to offer will require different historical methods and tools from those that have so far predominated in film history. Instead, these tools are likely to be drawn from the methodological dialogues of social and cultural historians. To begin with, we will need detailed historical maps of cinema exhibition, telling us what cinemas were where and when, amplified by whatever detailed evidence we can recover about the nature and frequency of attendance - precisely the kind of scholarly work pioneered by Karel Dibbets and the Cinema Context Collections project. ${ }^{95}$ This data then needs to be combined with broader statistical information derived from census data and other surveys to amplify our understanding of cinema's audiences - of the extent, for example, to which the geography of cinema produced new forms of social differentiation at the same time that the images its audiences consumed, projected a dissolution of 'the sumptuary lines between classes'. ${ }^{96}$

Such detailed quantitative information is vital if we are to progress beyond our current broad-brush knowledge based on trade figures, diplomatic accounts and grand theories of classical cinema as vernacular modernism. As vital, however, is the inclusion of experience that will ground quantitative generalisations in the concrete particulars of microhistorical studies of local situations, effects and infrastructure, based perhaps around the records of individual cinemas or small chains. The heroes of these microhistories - the Menocchios of the cinema - will be the small businessmen who acted as cultural brokers, navigators and translators of the middle ground constructing a creolised culture out of their community's encounters with the mediated external world. ${ }^{97}$ One of these microhistories may become the Montaillou of cinema history, through what it may reveal about how its citizen consumers explained themselves and their place in the world through their encounters with the forces of global and globalising culture..$^{8}$ Such histories, self-consciously acknowledging their own constructions and mediations, may also form part of comparative local histories, and, finally, may underpin attempts to consider the cultural function and performance of individual movies in more secure social and cultural detail than we can presently achieve.

I C. MacCabe, 'Preface' to Slavoj Žižek, The Fright of Real Tears: Krzysztof Kieslowski between Theory and Post-Theory, London 200I, p. vii. Quoted in D. Bordwell, 'Slavoj Žižek: Say Anything', April 2005. http://www.davidbordwell.net/zizek-say-anything.htm (accessed 26 August 2006).

2 S. Higashi, 'In Focus: Film History, or a Baedeker Guide to the Historical Turn', Cinema Journal, vol. 44, n. I, Fall 2004, p. 94.

3 Ibid., p. 95.

4 Ibid., p. 96. 
5 H. White, Metahistory: The Historical Imagination in Nineteenth-Century Europe, Baltimore I975; D. LaCapra, History and Criticism, Ithaca Ny I985. See also A. Munslow, Deconstructing History, London I997; C. Behan McCullagh, The Truth of History, London I998.

6 H. White, 'Historical Texts as Literary Artifact', in: Tropics of Discourse: Essays in Cultural Criticism, Baltimore 1978 , p. 82 .

7 R. Berkhofer, 'The Challenge of Poetics to (Normal) Historical Practice', Poetics Today, vol. 9, I988, p. 435-452; J. F. Klenotic, 'The Place of Rhetoric in "New” Film Historiography: The Discourse of Corrective Revisionism', Film History, vol. 6, I994, p. 45.

8 A. Marwick, 'Author's Response to a Review by Alan Munslow [of Arthur Marwick, The New Nature of History: Knowledge, Evidence, Language, London 200I]', http://www.history.ac.uk/ discourse/marwick2.html (accessed 27 August 2006).

9 J. Gaines, 'Film History and the Two Presents of Feminist Film Theory', Cinema Journal, vol. 44, n. I, Fall 2004, p. II6; C. MacCabe, 'Realism and the Cinema: Notes on Some Brechtian Theses', Screen, vol. 15, n. 2, Summer I974, p. 7-22.

Io A. Kuhn and J. Stacey, 'Screen Histories: An Introduction', in: A. Kuhn and J. Stacey (ed.), Screen Histories: A Screen Reader, Oxford I998, p. 3. The most striking example of the subsumption of historical analysis to what Kuhn and Stacey call Screen's 'theoretical-political agenda', which has lost none of its power to register the mutual incomprehension between competing discourses, is Christopher Williams's addendum, 'The Deep Focus Question: Some Comments on Patrick Ogle's Article', Screen, vol. I3, n. I, I97I, reprinted in: John Ellis (ed.), Screen Reader 1, London I977, p. IOg-II2.

II In addition to the work of Douglas Gomery cited below, examples would include T. Balio, United Artists: The Company Built by the Stars, Madison I976; T. Balio (ed.), The American Film Industry, Madison 1976; R. Allen, Vaudeville and Film 1895-1915: A Study in Media Interaction, New York I980.

I2 B. Klinger, 'Film History Terminable and Interminable: Recovering the Past in Reception Studies', Screen, vol. 38, n. 2, I997, p. III. Haden Guest provides a valuable account of the work of an earlier generation of American film historians to establish more rigorous standards of evidence in the compilation of filmographies. H. Guest, 'Experimentation and Innovation in Three American Film Journals of the I950s', in: L. Grieveson and H. Wasson (ed.), Inventing Cinema Studies, Durham forthcoming.

I3 D. Gomery, 'Writing the History of the American Film Industry: Warner Bros. and Sound', Screen, vol. I7, n. I, Spring I976, p. 4I.

I4 R. Allen and D. Gomery, Film History: Theory and Practice, New York I985, p. 46. 'The basis of the present work, the sources of its material, are memoirs, diaries, letters, diplomatic reports, and original narratives of eyewitnesses; other writings were used only if they were immediately derived from the above mentioned or seemed to equal them because of some original information. These sources will be identified on every page.' L. von Ranke, 'Preface: Histories of the Latin and German Nations from I494-I5I4'(1824), in: F. Stern (ed.), The Varieties of History, from Voltaire to the Present, New York I972, p. 56.

I5 Allen and Gomery, Film History: Theory and Practice, p. 4I; Klenotic, 'The Place of Rhetoric in “New” Film Historiography', p. $5 \mathrm{I}$.

I6 T. Elsaesser, 'The New Film History', Sight and Sound, vol. 55, n. 4, Autumn I986, p. 248.

I7 Klenotic, 'The Place of Rhetoric in "New" Film Historiography', p. 46.

I8 P. Rosen, Change Mummified: Cinema, Historicity, Theory, Minneapolis 2003, p. xxi.

I9 R. Abel, The Red Rooster Scare: Making Cinema American, 1900-1910, Berkeley I999; R. Vasey, The World According to Hollywood, 1919-1939, Exeter 1997.

20 T. Kuhn, The Structure of Scientific Revolutions, Chicago I962. David Bordwell describes 'ordinary criticism' as being, like Kuhn's 'normal Science', 'the ongoing program of a group of researchers using approved problem/solution routines to expand and fill out the realm of the known'. D. Bordwell, Making Meaning: Inference and Rhetoric in the Interpretation of Cinema, Cambridge MA I989, p. 25. During an extended research visit to the us in I984, I devised a grand plan for the construction of American cinema history: a small graduate school, taking in perhaps a dozen 
students per year, each of whom would produce an index of one year of a trade paper, around which they would also write a thesis. Having recently read David Lodge's Changing Places (London I975), I situated this place of scholarship in the State University of Euphoria, which was located on the border between Northern and Southern California. Unfortunately, there is no euphoric state between Northern and Southern California, and this work remains to be done. But if it had, we would now have a computerised searchable database of the trade press, combined with the results of twenty years' industry scholarship: a couple of dozen detailed studies of executive decision-making in the studio system, several comparisons of distribution practice among the major companies, chronological maps of the clearance system, accounts of regional variations in the relationship between cinema exhibition and mass retailing.

2I Rosen, Change Mummified, p. xxi-xxii.

22 Ibid., p. I27.

23 E.H. Carr, What Is History?, London I96I, p. 29; K. Jenkins, Rethinking History, London I99I, p. I9.

24 G.G. Iggers, Historiography in the Twentieth Century, Middletown CN I997, p. II.

25 L. Stone, 'History and Postmodernism', Past and Present, vol. I35, May I992, p. I94; Iggers, Historiography in the Twentieth Century, p. I45.

26 C. Ginzburg, 'Checking the Evidence: The Judge and the Historian', Critical Inquiry, vol. I8, n. I, Autumn I99I, p. 83-84.

27 C. Ginzburg, 'Microhistory: Two or Three things that I Know About It', Critical Inquiry, vol. 20, n. I, Autumn I993, p. 32, p. 28.

28 Rosen, Change Mummified, p. 388 , note 28.

29 C. Gledhill and L. Williams, 'The Return to History', in: C. Gledhill and L. Williams (ed.), Reinventing Film Studies, London 2000, p. 297-298.

30 Vivian Sobchack, 'What is Film History?, or, the Riddle of the Sphinxes', in: C. Gledhill and L. Williams (ed.), Reinventing Film Studies, London 2000, p. 301.

3I Ibid., p. 308.

32 Ibid., p. 310, p. 308.

33 In his I977 essay, 'On the Writing of the History of the Cinema', Geoffrey Nowell-Smith wrote that "no one now accepts accounts of film history (...) which pass blandly from one "fact" to another (...) And yet no one knows how to do better, except at a cost of a sceptical unwillingness to do anything.' G. Nowell-Smith, 'On the Writing of the History of the Cinema: Some Problems', in: Edinburgh '77 Magazine: History/Production/Memory, Edinburgh I977, p. Iо.

34 In their introduction to Film History: An Introduction, Kristin Thompson and David Bordwell articulate their ambition as being 'to sum up the history of film as it is presently conceived, written, and taught by its most accomplished scholars', but they also qualify the scale of their project by insisting that 'there is no single narrative of film history hat accounts for all events, causes and consequences. And the variety of historical approaches guarantees that historians will draw diverse and dissenting conclusions. (...) When historians focus on different questions, turn up different evidence, and formulate different arguments, we have not a single history but a diverse set of historical arguments.' K. Thompson and D. Bordwell, Film History: An Introduction, New York I994, p. xxvixxvii.

35 J. Mitry, 'De quelques problèmes d'histoire et d'esthétique de cinema', Cahiers de la cinémathèque, vol. IO-II, Summer-Autumn I973, p. II5. Translated and quoted in R. Abel, “ “Don’t Know Much about History”, or the (In)vested Interests of Doing Cinema History', Film History, vol. 6, n. I, I994, p. III.

36 M. Lagny, 'Film History: or History Expropriated', Film History, vol. 6, n. I, I994, p. 27, p. 4I.

37 B. Klinger, 'Film History Terminable and Interminable: Recovering the Past in Reception Studies', Screen, vol. 38, n. 2, Summer I997, p. IIo; F. Braudel, Capitalism and Material Life, 14001800, London i967, p. 44I-442.

38 Klinger, 'Film History Terminable and Interminable', p. II4.

39 Richard Abel, 'History Can Work for You, You Know How to Use It', Cinema Journal, vol. 44, n. I, Fall 2004, p. I08-Io9. 
40 C. Musser, 'Historiographic Method and the Study of Early Cinema', Cinema Journal, vol. 44, n. I, Fall 2004, p. I05.

4I G. R. Searle, A New England? Peace and War 1886-1918, Oxford 2004. My thanks to Luke McKernan for this reference.

42 P. Burke, What is Cultural History?, Cambridge 2004.

43 T. Miller, N. Govil, J. McMurria, R. Maxwell and T. Wang, Global Hollywood 2, London 2004, p. 3I.

44 Ibid., p. 45.

45 J. Hay, 'Piecing Together What Remains of the Cinematic City', in: D. B. Clarke (ed.), The Cinematic City, London I997, p. 2I0-2I2.

46 Ibid., p. 213-2I4, p. 223.

47 L. Grieveson, 'Woof, Warp, History', Cinema Journal, vol. 44, n. I, Fall 2004, p. I2I-I22.

48 Ibid., p. I24; 'In a total history, the analyst studies complex interactive environments or levels of society involved in the production of a particular event, effecting a historical synthesis, an integrated picture of synchronic as well as diachronic change.' Klinger, 'Film History Terminable and Interminable', p. Io8-ıo9.

49 D. Bordwell, 'Film and the Historical Return' (March 2005). http://www.davidbordwell. net/film-historical-return.htm (accessed 26 August 2006).

50 H. Blumer and P. Hauser, Movies, Delinquency and Crime, New York I933, p. I34-I35.

5I For a more elaborated version of this argument, see R. Maltby, “'A Brief Romantic Interlude”: Dick and Jane Go to Three-and-a-Half Seconds of the Classical Hollywood Cinema', in: D. Bordwell and N. Carroll Post-Theory: Reconstructing Film Studies, Madison I996, p. 434-459; R. Maltby, 'Why Boys Go Wrong: Gangsters, Hoodlums and the Natural History of Delinquent Careers', in: L. Grieveson, E. Sonnett and P. Stanfield (ed.), Mob Culture: The American Gangster Film, New Brunswick N 2005 , p. 4I-66.

52 T. Gunning, 'Systematizing the Electric Message: Narrative Form, Gender, and Modernity in the lonedale operator', in: C. Keil and S. Stamp (ed.), American Cinema's Transitional Era: Audiences, Institutions, Practices, Berkeley 2004, p. 44; T. Gunning, 'The Whole Town's Gawking: Early Cinema and the Visual Experience of Modernity', Yale Journal of Criticism, vol. 7, n. 2, I994, p. I89-201.

53 Gunning, 'Systematizing the Electric Message', p. 44; D. Bordwell, On the History of Film Style, Cambridge MA I997, p. I39-I46, p. 30I-302, note Ioo; C. Keil, “To Here from Modernity”: Style, Historiography, and Transitional Cinema', in: C. Keil and S. Stamp (ed.), American Cinema's Transitional Era: Audiences, Institutions, Practices, Berkeley 2004, p. 53-54.

54 B. Singer, Melodrama and Modernity: Early Sensational Cinema and Its Contexts, New York 200I, p. I04, p. I28. Lee Grieveson explores the relationship between early twentieth-century studies of cinema and contemporaneous work in sociology and psychology on subjectivity and social control in his chapter, 'Mimesis at the Movies: Cinema Studies and the conduct of Conduct', in: L. Grieveson and H. Wasson (ed.), Inventing Cinema Studies, Durham forthcoming.

55 Singer, Melodrama and Modernity, p. II8, p. I27.

56 Keil, 'To Here from Modernity', p. 52

57 Bordwell, On the History of Film Style, p. 302, note Ioo.

58 J. Staiger, 'The Future of the Past', Cinema Journal, vol. 44, n. I, Fall 2004, p. I28-I29.

59 Lagny, 'Film History: or History Expropriated', p. 4I; S. Kracauer, From Caligari to Hitler: A Psychological History of the German Film, Princeton I947, p. 6, p. 8; R. Maltby, 'The Politics of the Maladjusted Text', in: Ian Cameron (ed.), The Movie Book of Film Noir, London I992, p. 39-48.

60 Lagny, 'Film History: or History Expropriated', p. 4I.

6r Bordwell, 'Film and the Historical Return'. See also D. Bordwell, 'Contemporary Film Studies and the Vicissitudes of Grand Theory' and N. Carroll, 'Prospects for Film Theory: A Personal Assessment', both in: D. Bordwell and N. Carroll (ed.), Post Theory: Reconstructing Film Studies, Madison 1996 , p. $27 \mathrm{ff}$, p. 37-70.

62 J. Sedgwick et al, 'Proposal for a cost Action on the History of Film Exhibition and Reception', unpublished paper, September 2004. 
63 B. Bowles and N. Huggett, 'Cowboys, Jaffas and Pies: Researching Cinemagoing in the Illawarra', in: R. Maltby and M. Stokes (ed.), Hollywood Abroad: Audiences and Cultural Exchange, London 2004, p. 64-77.

64 Maurice Thorez, I8 April I948, quoted in J.-P. Jeancolas, 'From the Blum-Byrnes Agreement to the GatT Affair', in: G. Nowell-Smith and S. Ricci (ed.), Hollywood \& Europe: Economics, Culture, National Identity, 1945-95, London I998, p. 5I.

65 Leo Lowenthal, quoted in Grieveson, 'Mimesis at the Movies.' The history of the 'disciplinarisation' of film studies, and in particular its establishment as a critically-based humanities subject and its divorce from earlier connections to the social sciences and communication studies, is traced in several essays in Inventing Cinema Studies, and in particular in Lee Grieveson and Haidee Wasson's 'Introduction: on the Histories of Studying Cinema'.

66 E. Le Roy Ladurie, The Territory of the Historian, Chicago I979, p. 285; E. P. Thompson, The Making of the English Working Class, London I963, p. I2. See also F. Furet, 'Quantitative History', in: F. Gilbert and S. R. Grubard (ed.), Historical Studies Today, New York 1972.

67 Thompson, The Making of the English Working Class, p. I3.

68 Ginzburg, 'Checking the Evidence', p. 89-90.

69 Iggers, Historiography in the Twentieth Century, p. I03.

70 G. Levi, 'On Microhistory', in: Peter Burke (ed.), New Perspectives on Historical Writing, University Park, PA I992, p. 9I-II3; G. Levi, Inheriting Power: The Story of an Exorcist, Chicago I988; C. Ginzburg, The Cheese and the Worms: The Cosmos of a Sixteenth-Century Miller, Baltimore MD I980.

7I Sobchack, 'What is Film History?', p. 303.

72 R. Allen, 'Home Alone Together: Hollywood and the Family Film', in: M. Stokes and R. Maltby (ed.), Identifying Hollywood's Audiences: Cultural Identity and the Movies, London I999, p. IO9-I3I.

73 Abel, 'History Can Work for You', p. Io9.

74 'What is Being Done for Motion Pictures', statement by Will H. Hays, London, 5 October I923, p. 8, in: D. Gomery (ed.), The Will Hays Papers (microfilm, Frederick M D I986), part I, reel I2, frame 8i3.

75 Quoted in S. Dumenco, 'Stopping Spin Laden', New York Magazine, I2 November $200 \mathrm{I}$. Accessed from http://www.newyorkmetro.com/nymetro/news/media/features/5379/index2.html.

76 Charles Evans Hughes, I924, quoted in J. Trumpbour, Selling Hollywood to the World, Cambridge 2002, p. 29.

77 Quoted in Dumenco, 'Stopping Spin Laden'.

78 Franklin Foer, quoted in 'Background Briefing: Culture Bombs', Australian Broadcasting Corporation National Radio Broadcast, 7 July 2002. Accessed at http://www.abc.net.au/rn/talks/ bbing/docs/bb_020707_culture.rtf.

79 Quoted in 'Background Briefing: Culture Bombs'.

80 R. Kuisel, Seducing the French: The Dilemma of Americanization, Berkeley I993, p. 237.

8I V. de Grazia, Irresistible Empire: America's Advance Through 2oth-Century Europe, Cambridge MA 2005, p. 3 .

82 R. Maltby, 'Introduction: The Americanization of the World', in: R. Maltby and M. Stokes (ed.), Hollywood Abroad: Audiences and Cultural Exchange, London 2004, p. I-20.

83 E.S. Rosenberg, Spreading the American Dream: American Economic and Cultural Expansion, 1890-1945, New York I982, p. 87-107, p. I22; Owen D. Young, speech, July I930, quoted in F. Costigliola, Awkward Dominion: American Political, Economic, and Cultural Relations with Europe, 19191933, Ithaca NY I984, p. I4O.

84 Young, quoted in Costigliola, Awkward Dominion, p. I53.

85 V. de Grazia, 'Mass Culture and Sovereignty: The American Challenge to European Cinema, I920-1960', Journal of Modern History, vol. 6I, March I989, p. 6o.

86 C. Frederick, Selling Mrs. Consumer, New York I929, p. 5.

87 G. Cross, An All-Consuming Century: Why Commercialism Won in Modern America, New York 2000 , p. I. 
88 Ibid., p. 2.

89 Ibid., p. 2I.

90 De Grazia, Irresistible Empire, p. 78-95.

9I Ibid., p. 446.

92 Ibid., p. I07.

93 C.J. McKenna, 'Tripartheidism in Early American Movie-Going: Tracing the Development of Tri-racial Theaters in Robeson County, North Carolina (I896-I940)', in: R. Maltby, M. Stokes and R. Allen (ed.), Going to the Movies: Hollywood and the Social Experience of Moviegoing, Exeter forthcoming.

94 S. Patten, The New Basis of Civilization, New York I907, p. 9.

$95 \mathrm{http} / /$ www.cinemacontext.nl/.

96 De Grazia, Irresistible Empire, p. I0o. An exemplary model for such a project can be found in J. Klenotic, 'Moviegoing and Everyday Life Outside the Movie Palace', in: R. Maltby, M. Stokes and R. Allen (ed.), Going to the Movies: Hollywood and the Social Experience of Moviegoing, Exeter forthcoming.

97 Ginzburg, The Cheese and the Worms.

98 E. Le Roy Ladurie, Montaillou: The Promised Land of Error, New York 1978. 